\title{
Interpersonal Function on Tour Commentaries: A Modality Study
}

\author{
Krisna Yudha Bakthi ${ }^{1}$, Zewitra ${ }^{2}$ \\ ${ }^{1,2}$ Politeknik Negeri Bandung \\ e-mail: krisna.yudha@ polban.ac.id ${ }^{1}$, zewitra@polban.ac.id ${ }^{2}$

\begin{tabular}{ccc}
\hline Diterima & Direvisi & Disetujui \\
$02-09-2021$ & $15-09-2021$ & $29-09-2021$
\end{tabular}

\begin{abstract}
Functioned as a social medium, tour commentaries are used by tour guides to interact and communicate with tourists, especially in explaining activities, locations, cultures, and knowledge regarding the place they are visiting. These commentaries bring interpersonal function that is realized through the use of modality. This current study, therefore, aims to (1) identify the use of modalities that bear the interpersonal function found in students' tour commentaries and (2) describe the meaning of the modalities used. This study employed descriptive qualitative and text analysis methods using Halliday's theory of modality. The data, 57 utterances containing modality, were obtained from tour commentaries of Tour and Travel Business Study Program's students of Politeknik Negeri Bandung. This study reveals the use of both modalization, to show 'probability' and 'usuality', and modulation, to show 'obligation' and 'inclination', on students' tour commentaries. The 'probability' and 'obligation' functions are most discovered. The results can be beneficial academically and practically. They can give insight into how tour guides apply modality in their tour commentaries.
\end{abstract}

Keywords: modality, modalization, modulation, tour commentaries

Abstrak- Difungsikan sebagai media komunikasi sosial, tour commentaries digunakan oleh pemandu wisata untuk berinteraksi dan berkomunikasi dengan wisatawan, terutama dalam menjelaskan kegiatan, lokasi, budaya, dan pengetahuan tentang tempat yang mereka kunjungi. Tour commentaries ini membawa fungsi interpersonal yang diwujudkan melalui penggunaan modalitas. Oleh karena itu, penelitian ini bertujuan untuk (1) mengidentifikasi penggunaan modalitas yang mengandung fungsi interpersonal yang ditemukan dalam tour commentaries siswa dan (2) mendeskripsikan makna dari modalitas yang digunakan. Penelitian ini menggunakan metode deskriptif kualitatif dan analisis teks menggunakan teori modalitas Halliday. Data 57 tuturan yang mengandung modalitas diperoleh dari tour commentaries mahasiswa Prodi Usaha Perjalanan Wisata Politeknik Negeri Bandung. Studi ini mengungkapkan penggunaan kedua modalisasi, untuk menunjukkan 'probability' dan 'usuality', dan modulasi, untuk menunjukkan 'obligation' dan 'inclination', pada tour commentaries siswa. Fungsi 'probability' dan 'obligation' paling banyak ditemukan. Hasilnya dapat bermanfaat secara akademis dan praktis, yaitu dapat memberikan wawasan tentang bagaimana pemandu wisata menerapkan modalitas dalam tour commentaries mereka.

Kata kunci: modalitas, modalisasi, modulasi, tour commentaries

\section{INTRODUCTION}

Language is a tool to develop interaction and connection between people (Feng \& Liu, 2010; Halliday \& Matthiessen, 2013). From the eye of Systemic Functional Linguistics, it brings three functions, namely ideational, textual, and interpersonal (Fowler, 2013). The ideational function is related to how language is utilized to express experience. The textual function is described by how language is arranged to build coherence. Meanwhile, the interpersonal function talks about how language is used to develop and maintain social interaction (Mair \& Fairclough, 1997).

The interpersonal function itself is realized by the use of modality. It can be interpreted as forms of clauses that depict the attitudes, statements, desires, and feelings of a speaker towards what is said. Modality can also state the position of speakers during a communication process (as a speaker or listener).

The interpersonal function of language can be seen, one of which, from tour commentaries text. This kind of text is used by tour guides to convey information regarding activities, locations, cultures, and knowledge about the place being visited. Not only have a certain structure, organization, and point of view, tour commentaries also bear a certain value and message. Besides, tour commentaries function as an important social medium as they give a significant sign to determine speakers' behavior and information conveyed (Darong, 2021; Fan \& Bao, 2019; Feng \& Liu, 2010; Määttä et al., 2021). 
Thus, proper use of modality is required in this kind of text in order to create effective tour commentaries that can assure the well-acceptance of information.

Students of Politeknik Negeri Bandung (Polban)'s Tour and Travel Business Study Program are prepared to work in the tourism sector; therefore, they should be able to master all the knowledge and skills including in delivering tour commentaries. The students are required to be able to develop professional communication, specifically in giving direction and explaining or giving information, which are completed by proper attitude and judgment to create a favorable relationship with tourists.

Driving by the above fact, this study aims to (1) identify the modalities to convey the interpersonal function used in students' tour commentaries and (2) describe the meaning of modalities used. The study is expected to give both theoretical and practical implications. From the theoretical point of view, the result can contribute to the enrichment of Systemic Functional Linguistics and modality theories. Meanwhile, practically, this study can give insight on how a proper tour commentary is made. Thus, it can be used by both tourism academicians and tour guides.

\section{Modality}

Modality can be defined as the use of certain system of clauses that bring interpersonal function, for it shows a speaker's judgment on the probability of what is said (Gerot \& Wignell, 1995). It is a complex area of a language structure that focuses on how a message is conveyed in the different ways (Eggins, 2004). Further, Halliday claims that modality is a speaker's assessment on what he is saying. Therefore, the meaning of an utterance lies between yes or no - between positive and negative (Halliday \& Matthiessen, 2013).

Modality can be classified in two categories, Halliday says, namely 'Modalization' (Proposition) and 'Modulation' (Proposal). These types and subtypes are presented in the following figure.

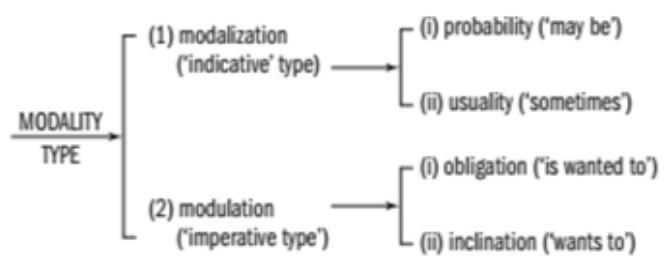

Source: M.A.K. Halliday and C.M.I.M. Matthiessen (2013) Fig 1. Types and Subtypes of Modality

a. Modalization
Modalization
signifies
positive

(asserting/affirming) and negative (denying) meanings. In the use within an utterance, modalization can bring two functions, namely 'probability' (possibly, probably, certainly) and 'usuality' (sometimes, usually, always) (Eggins, 2004). 'Probability' occurs when a speaker expresses his judgment of the possibility of something to happen. It bears the meaning of "maybe yes" or "maybe no". 'Usuality', on the other hand, occurs when a speaker expresses his judgment of the frequency with which something happens. It bears the meaning of "sometimes yes" or "sometimes no".

Modalization can be realized in three ways; by using the finite modal operator, modal adjunct of probability and usuality, and a combination of the two. They are presented in the following tables.

Table 1. Finite Modal Operator

\begin{tabular}{|c|c|c|c|c|}
\hline \multicolumn{5}{|c|}{ Modal operators: } \\
\hline & & Low & Medium & High \\
\hline \multirow[b]{2}{*}{ 总 } & 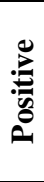 & $\begin{array}{l}\text { can, may, } \\
\text { could, } \\
\text { might, } \\
\text { dare }\end{array}$ & $\begin{array}{c}\text { will, } \\
\text { would, } \\
\text { should, } \\
\text { is/was to }\end{array}$ & $\begin{array}{l}\text { must, } \\
\text { ought to, } \\
\text { need, } \\
\text { has/had } \\
\text { to }\end{array}$ \\
\hline & Z & $\begin{array}{c}\text { needn't, } \\
\text { doesn't need } \\
\text { to, } \\
\text { didn't need } \\
\text { to, have to }\end{array}$ & $\begin{array}{c}\text { won't, } \\
\text { wouldn't, } \\
\text { shouldn't, } \\
\text { isn't/wasn't } \\
\text { to }\end{array}$ & $\begin{array}{l}\text { mustn't, } \\
\text { oughtn't } \\
\text { to, } \\
\text { can't, } \\
\text { couldn't, } \\
\text { mayn't, } \\
\text { mightn't, } \\
\text { hasn't to }\end{array}$ \\
\hline 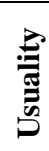 & & $\begin{array}{c}\text { sometimes, } \\
\text { occasionally, } \\
\text { ever, never }\end{array}$ & $\begin{array}{c}\text { usually, } \\
\text { often }\end{array}$ & always \\
\hline
\end{tabular}

Table 2. Modal Adjunct of Probability and Usuality

\begin{tabular}{ccc}
\hline Type & Meaning & Example \\
\hline Probability & $\begin{array}{c}\text { How } \\
\text { likely? }\end{array}$ & $\begin{array}{c}\text { probably, possibly, } \\
\text { certainly, perhaps, } \\
\text { maybe }\end{array}$ \\
\hline Usuality & $\begin{array}{c}\text { How } \\
\text { often? }\end{array}$ & $\begin{array}{c}\text { usually, sometimes, } \\
\text { always, (n)ever, often, } \\
\text { seldom }\end{array}$ \\
\end{tabular}

Source: M.A.K. Halliday (2004)

Here are several examples of using modalities to bear 'probability' and 'usuality' function.

i. That will be John, he will sit there all day. (Probability)

ii. It might be a debt collector. (Probability)

iii. That's probably John, he usually sits there all day. (Usuality)

iv. The store always smells good. (Usuality)

b. Modulation 
Modulation is the way a speaker expresses his judgment or attitude towards something. It brings two functions; to command and to offer. A command indicates an 'obligation' which makes someone do something (Eggins, 2004). It occurs when a speaker gives demand, suggestion, and advice to the listener. Meanwhile, an offer indicates desire or 'inclination' which means the tendency of speaker to do something or to make something happens. The degree of 'obligation' and 'inclination' can be separated into high, medium, and low.

Table 3. The Degree of Modulation Realization

\begin{tabular}{lccc}
\hline Realization & Low & Medium & High \\
\hline Obligation & $\begin{array}{c}\text { may, might, } \\
\text { can, could }\end{array}$ & $\begin{array}{c}\text { should, } \\
\text { shall, will, } \\
\text { would }\end{array}$ & $\begin{array}{c}\text { must, have } \\
\text { to, ought to, } \\
\text { need }\end{array}$ \\
\hline Inclination & willing & want to & $\begin{array}{c}\text { determine } \\
\text { to, need to }\end{array}$ \\
\hline
\end{tabular}

'Obligation' and 'inclination' function can be uttered in two ways, which are using the finite modal operators and predicators through verbal groups (passive verbs and adjectives).

Here are some examples of both functions arranged based on the degree.

\section{i. You should know that. (obligation) \\ ii. He ought to be going. (obligation) \\ iii. I want to lend you the Bostonians. (inclination) \\ iv. I'm willing to lend you the Bostonians. (inclination)}

The correlation between modalization and modulation towards the positive and negative polarization is illustrated in the following figure.

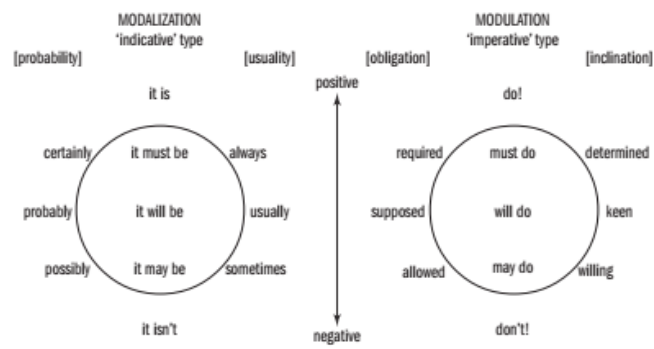

Source: M.A.K. Halliday and C.M.I.M. Matthiessen (2013)

Fig 2. Modalization and Modulation towards Polarization

\section{Tour Commentaries}

Tour commentary is a part of tourism narrative text presented by a tour guide during the tour (Travelbudee.com, 2017). It is used to describe and explain every aspect about a place, location, or country being visited (Olola, 2019). Besides, tour commentary is also beneficial to promote a tourist destination. It gives an insight for tourists to know and learn the history and culture of the place.

Tour commentary is composed based on a certain principle and structure (HjRay, 2019), which are:

a. Opening (introducing the location)

b. Content (the main explanation about the location)

c. Safety and health warning (a brief explanation about what should or should not do in the location)

d. Closing (ending the explanation when arrive at the location)

Besides having a certain structure, tour commentaries use certain modalities. Those modalities are applied to realize the above purposes and, at the same time, indicate the interpersonal function of the tour commentary texts.

\section{Review of Related Literature}

Research regarding modality from the eye of linguistics has been being favorable by many within decades. The focus and object of observation may vary.

A study on the use of modality in Obama's speech given at The White House Correspondents' Dinner in 2016 shows that The President tends to apply modalities in the medium level. The purpose is that the speech can be easily comprehended by his audiences (Chen \& Shuo, 2018). Similarly, Hillary Clinton and Donald Trump also employ the medium level of modal operators in order to make their speeches less aggressive (Ping \& Lingling, 2017). In addition, an observation of Joe Biden victory's speech finds that he uses modalities and pronoun "we" to indicate his close relationship with his people (Darong, 2021).

Another study focuses on the use of mood and modality in students' thesis writing. The result shows that all kinds of modality are found in students' thesis writing even though it is uncommon (Ngongo \& Naniana Benu, 2020). A study of epistemic modality in English academic texts reveals that modality is used to build social relationship. Besides, it functions to develop author's identity and the bonding between the author and the readers (Gao, 2012).

A systemic analysis of modality types, values, and orientations using SFL framework is conducted to the interpersonal function in English news discourse. The results show that modality is commonly used in micro-blogging news. Reporters are more likely to use the finite modal adjunct such as "will" to express his emotion. The modal "would" is another popular one to use in order to state reporters' expectation, determination, view, 
and attitude towards a certain event. Both "will" and "would" belong to the medium level (Rui \& Jingxia, 2018).

Another study on interpersonal meaning is conducted to the public service advertisements of Environmental Protection. The study compares ads written in two different languages and cultures. The results show that English advertisements tend to use the low-level modalities to bring the interpersonal function while Chinese advertisements choose the high one (Yang \& Gao, 2020).

The study on modality found in students' tour commentaries, to the best of the authors' knowledge, has never been conducted previously. Thus, this present study will fill the gap. The analysis on students' tour commentaries is imperative to discover the types and meaning of modalities they use.

\section{RESEARCH METHODOLOGY}

This study employed the descriptive qualitative method to analyze the use of modality found in tour commentaries. The data were taken from tour commentaries produced by students of Polban's Tour and Travel Study Program. By using the text analysis approach, the tour commentaries were transcribed and observed. It resulted in 57 utterances containing modality.

Those utterances were classified onto the table of the research instruments. With the Systemic Functional Linguistics (SFL) framework, the modality theory was employed to analyze the data. SFL approach is able to show the relationship between language and its function as a communication tool in real use. Moreover, based on the modality theory, the data were classified into two categories, namely modalization which includes 'probability' and 'usuality', and modulation which includes 'obligation' and 'inclination'.

Finally, those data were analyzed using the theory of interpersonal function. The results showed the meaning and function of using certain modality in tour commentaries texts.

\section{RESULT AND DISCUSSION}

The data selection step resulted in 57 utterances containing modality. Those utterances were classified into modalization to show 'probability' and 'usuality' and modulation to show 'obligation' and 'inclination'. The following chart presents the distribution of the data in each type of modality.

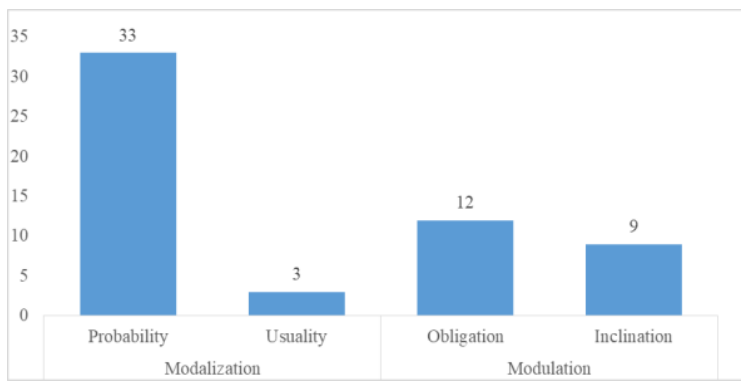

Fig 3. The Distribution of Types of Modalities

The chart shows that both modalization and modulation are found in the data observed. Of 57 data, modalization used to show 'probability' is found in 33 cases $(58 \%)$ while those used to show 'usuality' are only found in 3 cases $(5 \%)$. On the other hand, modulation used to show 'obligation' is found in 12 cases $(21 \%)$ while those used to show 'inclination' are found in 9 cases $(16 \%)$. Each is explained in the following part.

1. Probability

'Probability' occurs in the utterance that contains a speaker's judgment of what is or is not going to happen. Of 57 data observed, 33 of them $(58 \%)$ contain modalities that bring 'probability' function, such as:

a. As you can see the weather looks great. That is why I am delighted to welcome you first to the city of love.

\section{b. I will be your tour guide in our first attraction.}

c. Around the area we can see the imperishable beauty of the mansion.

\section{d. You can feel the cold breeze during the night.}

The degree of probability is divided into three; possibly, probably, and certainly. According to context observation, modalities in the above utterances are used by speakers (tour guides, in this case) to state the probability of certainty. Those modalities function to inform something certain. In utterance $a$, modal can is used by the tour guide to give vivid information that the weather is nice, and he feels delighted to welcome the tourists. In utterance $b$, the tour guide states that he, for certain, will guide the tourists in the first attraction. In utterance $c$, modal can is used by the tour guide to assure the tourists that they are going to enjoy a beautiful place. Similarly, in utterance $d$, the tour guide assures the tourists that they are going to enjoy the cool breeze at night.

The utterances presented above use two modal words; can and will. According to the degree of the finite modal operator, can has a low degree while will has a medium degree. It implies that the degrees of probability in students' tour commentaries 
are low and medium.

2. Usuality

'Usuality' occurs in the utterance that contains a speaker's judgment of the frequency of something to happen. Of 57 data observed, only 3 of them $(5 \%)$ contain modalities that bring 'usuality' function, such as:

a. In case of emergency, don't hesitate to approach me as I am always ready with my first aid kit.

b. There is always something about amusement parks that makes even the most charged adults feel like an innocent, carefree, and child again.

Referring to the analysis of context, the above utterances bring 'usuality' function. the use of always indicates the speakers' (in this case, tour guides) judgment of the frequency of something to happen. In utterance $a$, the tour guide assures the tourists that he is always ready with the first aid kit. In utterance $b$, similarly, the tour guide says that everybody is always fond of an amusement park.

The modal word used in the above utterances is always. According to the degree of the finite modal operator, it has a high degree. This implies that the degree of "usuality" in students' tour commentaries is high.

\section{Obligation}

'Obligation' occurs in the utterance that contains a speaker's command, suggestion, demand, and advice that make someone do something. Of 57 data observed, 12 of them $(21 \%)$ contain modalities that bring 'obligation' function, such as:

a. Always wear your facemask, face shield, and bring alcohol at all times for sanitation.

b. Always maintain social distancing while practicing good respiratory hygiene.

c. I stacked for instruction, always pay attention to my signals indicated by a whistle and a flag.

d. Always remember the word Lego, clean as you go.

e. Note that leave the place as clean as it is, for we must bear in mind that take nothing but pictures and leave nothing but footprints.

The statement that brings 'obligation' function is not always uttered in the form of imperative sentence. Utterances $a$ to $d$ are imperative sentences but utterance $e$ is not. However, all of them function to state the speakers' (tour guides, in this case) commands or suggestions, specifically those related to safety and regulation that tourists should comply with. In utterance $a$ and $b$, for example, the tour guide urges the tourists to always maintain the health protocol. Meanwhile, in utterance $c$, the tour guide commands the tourists to always pay attention to the signals given. Also, in utterance $d$, the tour guide reminds the tourists to keep the place clean. The similar message is also conveyed in utterance $e$ even though using different type of modal word.

The above utterances use modal words always and must. According to the degree of the finite modal operator, both have a high degree. Therefore, it can be said that the degree of 'obligation' in students' tour commentaries is high.

4. Inclination

'Inclination' occurs in the utterance that contains a speaker's offer of something to happen or a speaker's desire to do something. Of 57 data observed, 9 of them $(16 \%)$ contain modalities that bring 'inclination' function, such as:

a. My name is Croasynova but you can call me Nova.

b. I want all of you to synchronize your time with me so that no one will be left behind.

c. You are given a sign that you should be able to talk to the people.

In those three examples, the modal words can, want to, and should are used to state the speakers' desire of something to happen. In utterance $a$, for instance, the tour guide uses modal can to ask the tourists to call her Nova. In utterance $b$, the tour guide wants the tourists to do something for him, which is to synchronize the time. Meanwhile, in utterance $c$, the tour guide asks the tourists to interact with local people.

According to the degree of the finite modal operator, can and should are categorized into low degree modals while want to has a medium degree. It implies that the degrees of 'inclination' in students' tour commentaries are low and medium.

From the above discussion, it can be seen that 'probability' (certainty) and 'obligation' functions are the most used (33 and 12 cases out of 57, respectively). In implies that the contents of students' tour commentaries are mostly applied to state the probable situation that most likely to happen and to declare what should or should not do by tourists. On the other hand, 'usuality' and 'inclination' functions are not commonly used the tour commentaries texts.

\section{CONCLUSION}

Tour commentary functions as a social medium that creates a link between tour guides and 
tourists. It is used by tour guides to direct tourists and give information regarding places that they are visiting during the tour. Thus, from the SFL point of view, this typical discourse brings the interpersonal function of language.

In the practice, the interpersonal function is realized by the use of modality which, by type, bears certain meanings. The observation towards students' tour commentaries finds the use of both modalization ('probability' and 'usuality') and modulation ('obligation' and 'inclination'). Nevertheless, 'probability' and 'obligation' are the most used.

'Probability' has certain levels; possibly, probably, and certainly. In students' tour commentaries, the utterances with certainly meaning are most found. It implies that the tour guide has done good preparation before delivering a tour commentary. He has done observation towards the locations or attractions and has mastered the content of his commentary since he has to make sure that everything runs as planned.

On the other hand, the use of utterances with 'obligation' implies that there are some strict rules that must be obeyed during the trip. The rules can be related to the location or attraction visited, the schedule of the trip, or in this pandemic situation, the health protocol. A tour guide has to make sure that all rules are followed, and all tourists are safe and healthy. Thus, the degree of obligation given is high.

The results of this study can contribute to both academic and practical usage. In the academic or theoretical fields, the results can enhance our understanding of Systemic Functional Linguistics study, especially regarding modality. In the practical field, this study can give insight into how a proper tour commentary is made. Thus, it can be used by both tourism academicians and tour guides.

Despite the importance of this study, it sure has some limitations. First, the data observed were limited. It only used 57 data from five tour commentaries. Besides, the data were gotten only from Polban students. Thus, for more comprehensive results, future researchers are recommended to use a wider range of data which source from professional tour commentaries.

\section{REFERENCE}

Chen, D., \& Shuo, Z. (2018). Analysis of Interpersonal Function in Speech-A Case Study in Obama's WHCD Address. International Journal of Liberal Arts and Social Science, 6(8), 31-40. https://ijlass.org/data/frontImages/articles/Vol

\section{.6No.8/4.31-40.pdf}

Darong, H. C. (2021). Interpersonal Function of Joe Biden's Victory Speech (Systemic Functional Linguistics View). Journal of Education Research and Evaluation, 5(1), 57. https://doi.org/10.23887/jere.v5i1.31420

Eggins, S. (2004). An Introduction to Systemic Functional Linguistics 2nd Edition (2nd ed.). Continuum.

Fan, M., \& Bao, C. (2019). Interpersonal Function Analysis of Discourse from the Perspective of Critical Discourse Analysis. 179(Ieesasm 2017), 218-223. https://doi.org/10.2991/ieesasm-17.2018.45

Feng, H., \& Liu, Y. (2010). Analysis of Interpersonal Meaning in Public SpeechesA Case Study of Obama's Speech. Journal of Language Teaching and Research, 1(6), 825829. https://doi.org/10.4304/jltr.1.6.825-829

Fowler, R. (2013). Language in the news: Discourse and ideology in the press. In Language in the News: Discourse and Ideology in the Press. https://doi.org/10.4324/9781315002057

Gao, Q. (2012). Interpersonal functions of epistemic modality in Academic English Writing. Chinese J. Appl. Linguist. https://search.proquest.com/openview/b2c36b dfbca9750ac44dc839e206d541/1?pqorigsite $=$ gscholar $\& \mathrm{cbl}=2031357$

Gerot, L., \& Wignell, P. (1995). Making Sense of Functional Grammar: An Introductory Workbook. Gerd Stabler.

Halliday, M. A. K., \& Matthiessen, C. M. I. M. (2013). Halliday's introduction to functional grammar: Fourth edition. In Halliday's Introduction to Functional Grammar: Fourth Edition.

https://doi.org/10.4324/9780203431269

HjRay. (2019). Tour Commentary Delivery. https://geotrainingstudio.com/2019/08/13/cu4 -tour-commentary-delivery/

Määttä, S. K., Puumala, E., \& Ylikomi, R. (2021). Linguistic, psychological and epistemic vulnerability in asylum procedures: An interdisciplinary approach. Discourse Studies, 23(1), 46-66. https://doi.org/10.1177/1461445620942909

Mair, C., \& Fairclough, N. (1997). Critical Discourse Analysis: The Critical Analysis of Language. In Language (Vol. 73, Issue 1). https://doi.org/10.2307/416612 
Ngongo, M., \& Naniana Benu. (2020). Interpersonal and Ideational Metaphors in the Writing of Thesis Texts of Undergraduate Students of English Study Program: A Systemic Functional Linguistic Approach. RETORIKA: Jurnal Ilmu Bahasa, 6(2), 113120. https://doi.org/10.22225/jr.6.2.2320.113120

Olola, P. (2019). The Tour Commentary. https://www.slideshare.net/pauliuslaiminga/th e-tour-commentary

Ping, K., \& Lingling, L. (2017). Application of Interpersonal Meaning in Hillary's and Trump's Election Speeches. Advances in Language and Literary Studies, 8(6), 28. https://doi.org/10.7575/aiac.alls.v.8n.6p.28

Rui, Z., \& Jingxia, L. (2018). The Study on the Interpersonal Meanings of Modality in Micro-blogging English News Discourse by the case of "Donald Trump's Muslim Entry Ban." Advances in Language and Literary Studies, 9(2), 110. https://doi.org/10.7575/aiac.alls.v.9n.2p.110

Travelbudee.com. (2017). Component of a Good Commnetary.

http://blog.travelbuddee.com/componentsgood-tour-commentary/

Yang, X., \& Gao, W. (2020). A Contrastive Analysis of Interpersonal Function of Public Service Advertising in English and Chinese. Sino-US English Teaching, 17(3), 99-105. https://doi.org/10.17265/1539-

8072/2020.03.004 